\title{
Berchmansus elegans (Neuroptera: Chrysopidae): Larval and adult characteristics and new tribal affiliation*
}

\author{
Catherine A. TAUBER ${ }^{1}$, Maurice J. TAUBER ${ }^{1}$ and Gilberto S. AlBUQUERQUE ${ }^{2}$ \\ ${ }^{1}$ Department of Entomology, Comstock Hall, Cornell University, Ithaca, NY 14853-2601, USA; e-mail: cat6@cornell.edu \\ ${ }^{2}$ Laboratório de Entomologia e Fitopatologia, CCTA, Universidade Estadual do Norte Fluminense, Campos dos Goytacazes, \\ 28013-602 Rio de Janeiro, Brazil; e-mail: gsa@uenf.br
}

Key words. Chrysopidae, Belonopterygini, larvae, adults, morphology

\begin{abstract}
The genus Berchmansus Navás, which was previously assigned to the tribe Leucochrysini, consists of three very rare species, all described from the Neotropics and all poorly known. Our report (1) provides the first description of a Berchmansus larva, the first instar of Berchmansus elegans (Guérin Méneville), (2) illustrates and redescribes the B. elegans adult, with emphasis on male and female genitalia, and (3) examines the larval and adult characters vis-à-vis the tribal affiliation of the genus. Given that the B. elegans adult and first instar share many apomorphies with other belonopterygine genera, this species belongs in the cosmopolitan tribe Belonopterygini, rather than the New World tribe Leucochrysini. Although Berchmansus larvae have not been collected in the field, we suspect that, like other belonopterygines, they are associated with ant nests. B. elegans exhibits a number of highly modified and unusual structures, some of which (\#1 to \#5) are not reported for any other chrysopids. Specifically: Males have (1) a unique, quadrate, dome-like hood above the gonarcus and (2) large, coiled parameres on the gonosaccus. First instars have (3) a greatly enlarged subapical seta on the flagellum, (4) a transverse row of long, hooked setae along the dorso-anterior margin of the pronotum, and (5) setose laterodorsal tubercles on the meso- and metathorax, with (6) multi-pronged, hooked setae.
\end{abstract}

\section{INTRODUCTION}

The green lacewing genus Berchmansus Navás, 1913, provides a prime example that illustrates the essential contributions of larval morphology and comparative biology to the classification and phylogeny of Neuroptera (e.g., Stange \& Miller, 1990; Díaz-Aranda \& Monserrat, 1995; Aspöck et al., 2001; Monserrat et al., 2001; Tauber, 2003; Grebennikov 2004). Berchmansus contains three neotropical species that are very rare in collections and that have received very little attention. Navás (1913) erected the genus with a short description of external adult features. While presenting a brief summary of work in progress, Adams (1978) erected the Chrysopinae tribe Leucochrysini and assigned Berchmansus to it; he did not provide a definition of the tribe or additional information on the genus or the included species.

In their review of the green lacewings, Brooks \& Barnard (1990) restructured Leucochrysini to include taxa known only from the New World, and they retained Berchmansus (with its three species) within the Leucochrysini. Because of the paucity of specimens and the tenuous nature of the diagnostic characters, they were unable to confirm the monophyly of the genus. The genus is distinguished primarily by the position of the first radial crossvein, a feature that, like many aspects of the venation in the Chrysopidae, is probably variable within and among chrysopid taxa. They also described a unique component in the male genitalia of Berchmansus elegans (Guérin Méneville, 1844), an arcuate structure ventral to the gonarcus, and they provided a brief description of the Berchmansus adumbratus Navás, 1913, female genitalia.

In 2002 and 2003 we obtained eggs from fieldcollected adults of B. elegans; these eggs hatched and we preserved first instars; we were unable to rear subsequent stages. Features of our first instar specimens led us to suspect that $B$. elegans is more closely affiliated with the cosmopolitan tribe Belonopterygini than the New World tribe Leucochrysini. Consequently, we re-examined the adult morphological features that had led to the earlier assignment of Berchmansus to Leucochrysini. On the basis of both larval and adult characters, it is now evident that B. elegans' affiliation lies with Belonopterygini. We

\footnotetext{
* Dedication. We dedicate this paper to two highly distinguished neuropterologists, both of whom did pioneering work on Belonopterygini: Professor Maria Matilde Principi (University of Bologna), who recognized the uniqueness of Italochrysa and provided superb descriptions and drawings of both the adult and larva; and Professor Bo Tjeder (University of Lund, deceased 1992), whose admirable studies documented the characteristics and much of the diversity exhibited by Old World members of this chrysopid trib e.
} 


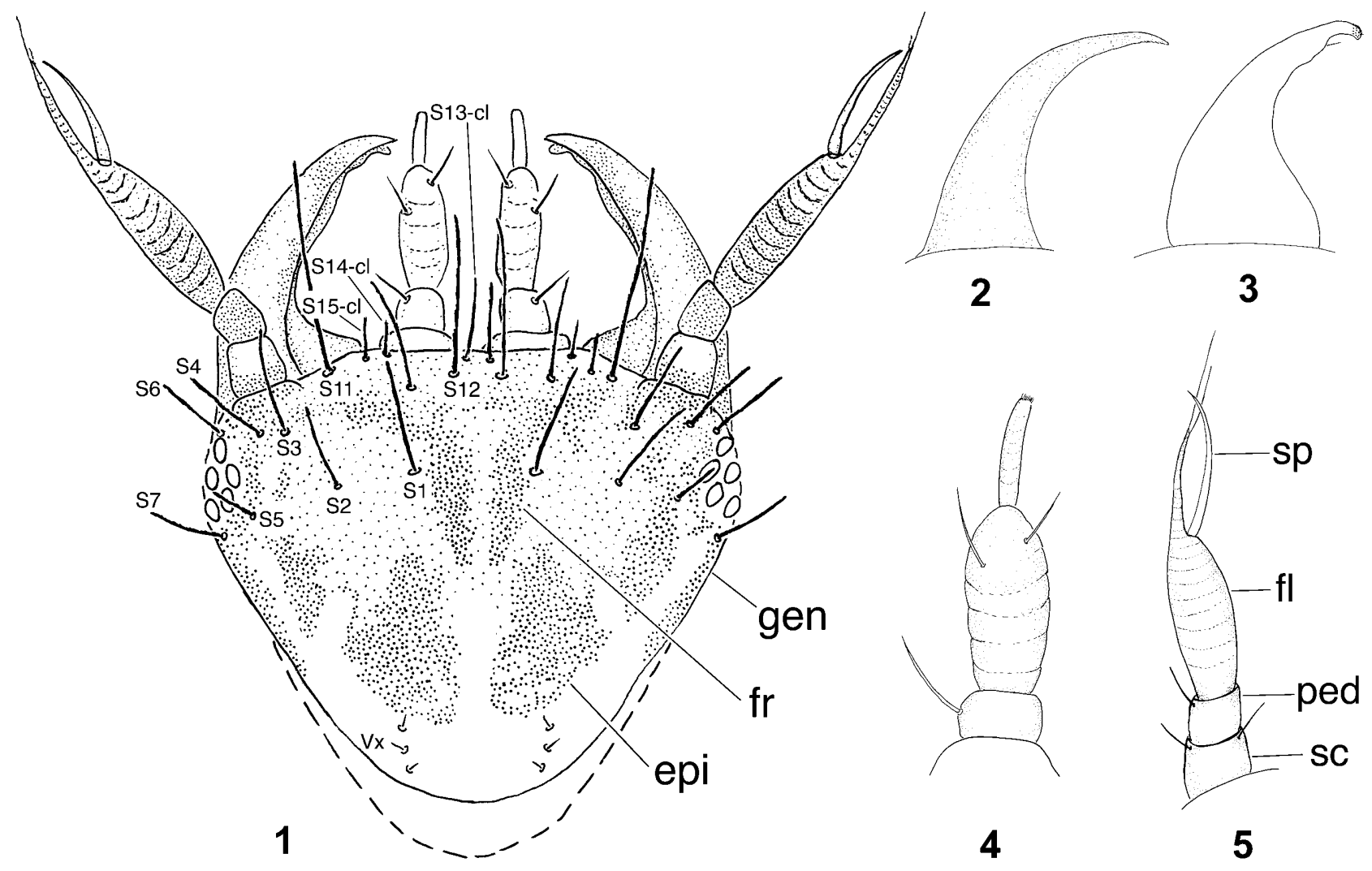

Figs 1-5. Berchmansus elegans, first instar. 1 - head dorsal; 2 - mandible; 3 - maxilla; 4 - labial palpus; 5 - antenna. epi - epicranial marking; fl - flagellum; fr - frontal marking; gen - genal marking; ped - pedicel; sc - scape; sp - spur; S1-S7, S11-S15, Vx primary setae. The pair of unlabelled setae below the labial palps in Fig. 1 are secondary setae.

also report that our specimens of male B. elegans differ notably from Brooks \& Barnard's (1990) descriptions and illustrations of the species*.

Our study here presents (1) a description of the B. elegans first instar, (2) redescriptions of B. elegans males and females, with emphasis on generic-level head, wing, and genital characters, and (3) a review of B. elegans larval and adult characters vis-à-vis the tribal affiliation of the genus. Specifically, we compare the B. elegans larvae and adults with previously described leucochrysines and belonopterygines (Larvae: Principi, 1946; New, 1983, 1986; Díaz-Aranda \& Monserrat, 1995; Tauber, 2004; Mantoanelli et al., 2006; Adults: Tjeder, 1966; Adams, 1977, 1979, 1987; Brooks \& Barnard, 1990; Tsukaguchi, 1995; Tauber, 2004). Finally, we propose (4) the transfer of $B$. elegans to the tribe Belonopterygini, and we identify (5) a suite of fifteen first instar characters that should be included in the phylogenetic analysis of higher-level lineages within the Chrysopidae.

\section{MATERIAL AND METHODS}

\section{Procedures and terminology}

The rearing, preservation, and descriptive procedures were presented earlier (Tauber et al., 1998, 2000). Nomenclature for adult characters (head, mouthparts, wings and genitalia) follow those in current usage (Snodgrass, 1935; Tjeder, 1966; Adams, 1977; Brooks \& Barnard, 1990; Tauber, 2003). Nomenclature for larval morphology follows that of Rousset (1966) for the head, and Tauber et al. (2000) and Tauber \& de Léon (2001) for the thorax and abdomen. Primary setae are designated with an "S" followed by a number, and in the case of appendages, a letter (or letters). Because chrysopids (all instars) consistently have three setae on the anterior margin of the clypeus (cl), we designate these setae as primary cephalic setae S13-cl, S14-cl, and S15-cl (see Fig. 1).

Measurements of both adult and larval head width were made across the widest part of the head and include the eyes. The ratio (head-width : eye-width) was the distance between the eyes across the vertex : mean width of left and right eyes (see Brooks \& Barnard, 1990). Wing width was measured at the widest part of the wing. Larval body length was measured along the curved midlateral line of distended specimens; head length was determined along the midline from the tip of the clypeus to the

\footnotetext{
* After this manuscript went to press, we had the opportunity to examine the types of B. elegans (male holotype and two female paratypes; Koninklijk Belgisch Instituut voor Natuurwetenschappen, Brussels). Consequently, we have confirmed the identity of our specimens as B. elegans. We also examined the specimens that Brooks \& Barnard (1990) referred to as "B. elegans" but that differed significantly from ours. We note that Brooks \& Barnard's figures of "B. elegans" actually refer to a new species of Berchmansus that closely resembles $B$. elegans externally, but has significantly different male genitalia and is slightly smaller. We thank J. Constant and D. Goodger for making the specimens available to us, and S. Brooks for calling our attention to the differences between his specimens and ours.
} 

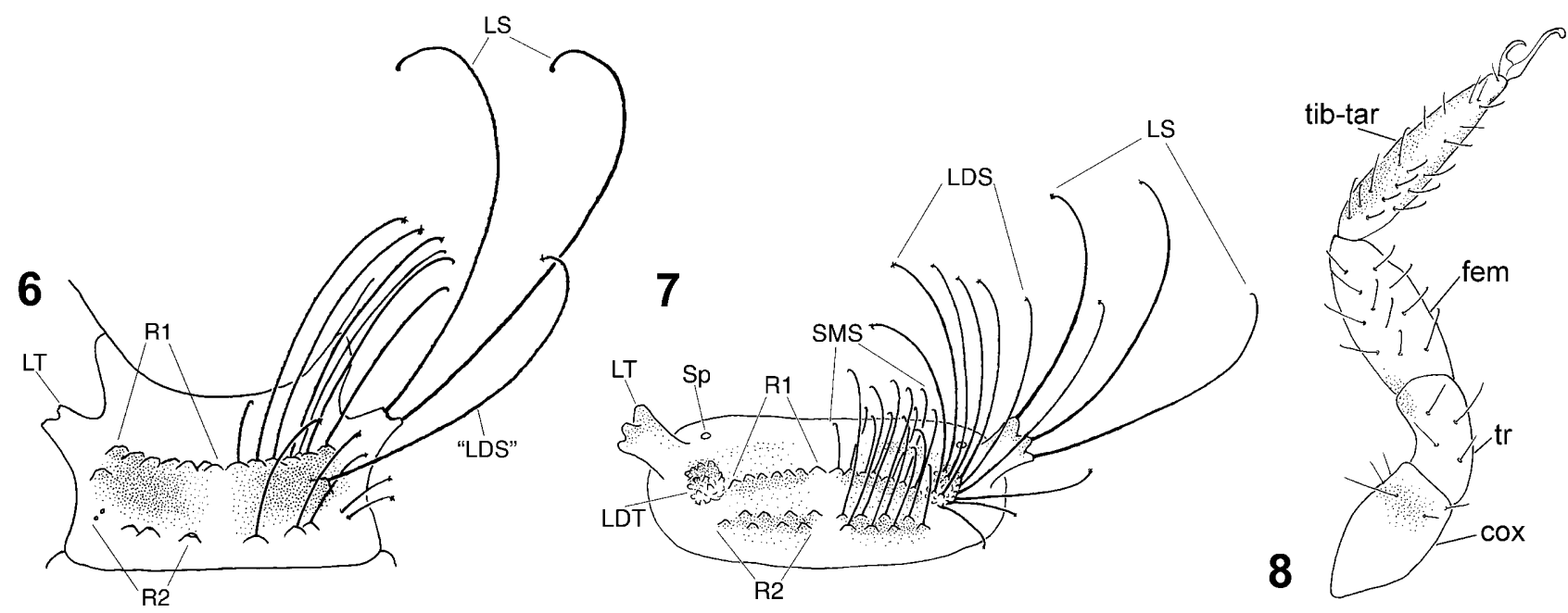

Figs 6-8. Berchmansus elegans, first instar. 6 - prothorax; 7 - mesothorax; 8 - right mesothoracic leg. cox - coxa; fem - femur; LDS - setae on laterodorsal tubercle; "LDS" - presumed homologue of LDS; LDT - laterodorsal tubercle; LS - setae on lateral tubercle; LT - lateral tubercle; R1, R2 - rows of setae; SMS - submedian setae; Sp - spiracle; tib-tar - fused tibia and tarsus; tr trochanter.

cervix; mandible length was measured along the center of the mandibles' curved dorsal surface. All measurements were made with image analysis software (Image-Pro Plus, Version 3).

\section{Specimens examined}

Adults: Brazil, Rio de Janeiro State (all sites in or near Desengano State Park in the northern part of the state): Babilônia farm, Pedrinhas farm, Santo Agustinho, Santo Antônio do Imbé, G.S. Albuquerque, M.J. Tauber, C.A. Tauber Expeditions April 2001, May 2002, April-May 2003; Espírito Santo State: Linhares, Vale do Rio Doce Natural Reserve: Pequi Vinagreiro Trail, Bicuíba Trail, G.S. Albuquerque, M.J. Tauber, C.A. Tauber Expedition, November 2003.

Larvae: Brazil, Rio de Janeiro State: Santo Agustinho (C\&MT Lots 2001:10, 2002:04); Santo Antônio do Imbé (C\&MT Lot 2003:10).

Voucher specimens (adults) are deposited in the insect collection of the Universidade Estadual do Norte Fluminense, Campos dos Goytacazes, Rio de Janeiro State, Brazil; the California Academy of Sciences, San Francisco; the United States National Museum, Washington, DC; and the research collection of M.J. and C.A. Tauber. Larvae are currently held in the research collections of G.S. Albuquerque and M.J. and C.A. Tauber.

\section{RESULTS}

\section{Berchmansus elegans (Guérin-Méneville, 1844) Descriptions}

\section{Instar I (Figs 1-15)}

Body small, compact, slightly thickened through mesothorax, metathorax, and anterior abdominal segments, but not abruptly raised; $1.05-1.53 \mathrm{~mm}$ long. Integument smooth, without spinules, bearing setae with smooth or rough surface, apex pointed, blunt or with single- or multi-pronged hook.

Head (Fig. 1): $0.29-0.32 \mathrm{~mm}$ wide; $\sim 0.22-0.24 \mathrm{~mm}$ long. Mandible (Fig. 2) short, broad basally; 0.148-0.180 mm long; 0.039-0.049 mm wide, at base; with $~ 5$ shallow teeth apically. Maxilla (Fig. 3) broad basally, constricted distally; apex rugulose dorsally and laterally, with single ventral seta, two microsetae near apex. Labial palp (Fig. 4) extending beyond mandible; basal segment with single long lateral seta; second segment broad $(0.039 \mathrm{~mm}$ wide at widest point; $0.076-0.080 \mathrm{~mm}$ long), without visible annulations, with two long setae near apex; terminal segment narrow, tubular, with several microsetae apically. Antenna (Fig. 5) with scape, pedicel quadrate, similar to each other in length and width (pedicel: 0.031-0.034 long, 0.033-0.041 mm wide). Flagellum large, over two times length of pedicel, subequal in width to pedicel; $0.087-0.101 \mathrm{~mm}$ long; $0.032-0.038 \mathrm{~mm}$ wide, at widest point; with subapical seta greatly enlarged, spur-like, curved anteromesally; terminus with two long, fine, apical setae. Chaetotaxy (Fig. 1). All primary cephalic setae present; S1-S7, S11-S12 blunt, with rough surface; S1, S11, S12 long; one pair of long secondary setae between S11 and S12, above antennal base; three pairs of clypeal setae anteriorly, one mesal (S13-cl), two above mandible (S14-cl, S15-cl); Vx with three short setae in longitudinal line, no pore detected. Coloration (Fig. 1). Dorsal surface mostly brown, except white posteriorly. Epicranial marking paired, globular, dark brown. Frontal marking paired, dark brown. Postfrontal marking not distinguished. Base of antenna, genal marking dark brown. Mandible, maxilla amber, base of mandible marked with dark brown laterally. Labial palp cream colored. Scape brown basally, white distally; pedicel, base of flagellum brown; distal half of flagellum cream-colored.

Thorax (Figs 6-8). Sclerites, setae associated with sclerites not distinguished. Prothorax (Fig. 6) with pair of lateral tubercles (LTs), each with two long, rough, knobbed terminal setae (LS) extending well beyond base of mandibles, no microsetae. Single long, curved seta arising from chalaza mesodorsal to LT, serrated throughout, with multi-pronged terminal hook. [Note: Given the position and structure of this seta, we consider it homologous with the LDS of the mesothorax and metathorax.]. 


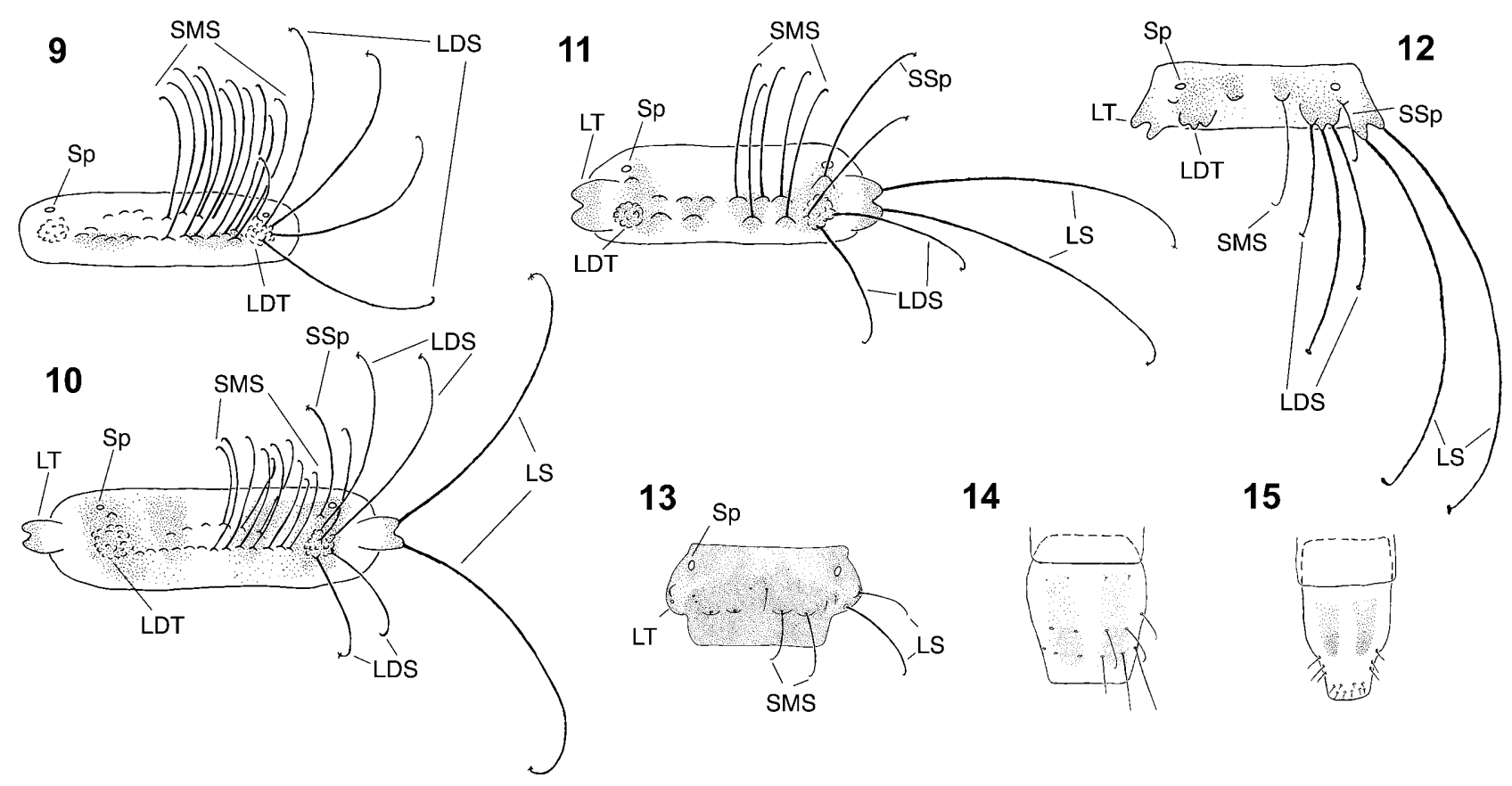

Figs 9-15. Berchmansus elegans, first instar, abdominal dorsum. 9 - segment 1; 10 - segments 2-5; 11 - segment 6;12 - segment $7 ; 13$ - segment $8 ; 14$ - segment 9;15 - segment 10. LDS - setae on laterodorsal tubercle; LDT - laterodorsal tubercle; LS - setae on lateral tubercle; LT - lateral tubercle; SMS - submedian setae; Sp - spiracle; SSp - seta associated with spiracle.

Anterior row (R1) of $\sim 14$ long, rough and smooth, hooked (single- and multi-pronged) setae arising from rounded chalazae, projecting anteriorly above cervix, almost to level of eyes, curving upward terminally. Posterior row (R2) of six mesal, hooked (smooth, multipronged) setae on round chalazae and four lateral (thin, smooth, hooked) setae. Mesothorax (Fig. 7) with pair of LTs each bearing three long, rough, apical LS; anterior two LS hooked (multi-pronged), posterior LS curved, pointed. Pair of laterodorsal tubercles (LDT) at base of LTs. LDTs large, spherical, each with 12 to 14 , mediumlength to long curved setae (LDS); LDS serrated or rough and terminating in single-pronged or multi-pronged hooks. Dorsum with two transverse rows of long, smooth, hooked (single-pronged) submedian setae (SMS) extending anteriorly from rounded chalazae; anterior row with $\sim 14$ SMS in single file; second row with 12-16 SMS in staggered row. Spiracle small, round, unraised, located at anteromesal base of LT; spiracular seta (SSp) absent. Metathorax. Similar to mesothorax except without spiracle, all three pairs of LS hooked (multi-pronged). Legs (Fig. 8). Coxae, femura with sparse smooth, pointed setae; tibiae apparently fused with tarsi, with numerous rough, hooked and blunt setae; tips of tarsi with long, smooth, pointed seta. Tarsal claws deeply cleft, slender; empodia long. Coloration. Dorsum white to creamcolored; each segment with light brown pigmented markings submesally; prothoracic, mesothoracic LTs, LDTs cream colored; metathoracic LTs, LDTs brown. Venter cream-colored with light brown mesal stripe. Legs white, except distal two-thirds of tibiae dark brown.

Abdomen (Figs 9-15). Segment 1 (Fig. 9). LT absent. Spiracle at base of laterodorsal tubercle (LDT) round, unraised; spiracular seta (SSp) unidentified. LDT bearing approximately five medium-length, curved, rough or serrated, hooked LDS (single- or multi-pronged). Dorsum with two transverse rows of long, curved, smooth, hooked SMS (single-pronged) arising from rounded chalazae projecting anteriorly; anterior row with eight SMS, posterior row with 14 SMS. Segments 2-5 (Fig. 10). LTs each with two long, curved, rough, hooked (single- and multipronged) LS, no microsetae. Spherical LDT at base of LT, bearing approximately two long, two to three shorter, curved, rough or serrated, hooked LDS (single- or multipronged). Spiracle and SSp at base of LT and LDT; SSp long, rough, hooked (multi-pronged). Dorsum of each segment with two transverse rows of long, smooth, hooked SMS on rounded chalazae: four to six SMS in each anterior row, ten to fourteen SMS in each posterior row. Segments 6-7 (Figs 11, 12). LTs each with two long, rough, multi-pronged, hooked LS, no microsetae. LDTs each bearing three long to medium-length, rough, hooked, (single- or multi-pronged) LDS. SSp on chalazae, thin, rough, hooked (single-pronged). A6: Two transverse rows smooth, hooked (single-pronged) SMS anterior row with six SMS, posterior with four SMS. A7: Two mesal SMS on chalazae, medium-length, slightly rough, hooked (single-pronged). Segment 8 (Fig. 13). LT short, round, with one long, one shorter, slightly rough, hooked LS, two very short setae at base; spiracle on anterior base of LT, SSp not distinguishable. Dorsum with two short, smooth, pointed, anterior SMS, four longer, rough, hooked (single-pronged) posterior SMS. Segment 9 (Fig. 14). Anterior half with row of four very small setae; posterior half with two transverse rows, each with six SMS, anterior ones slightly rough, slightly hooked, 

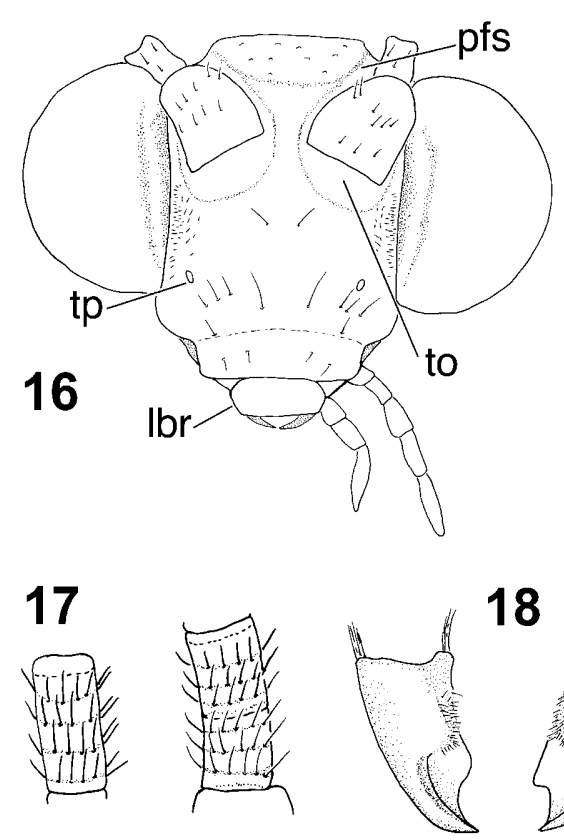

18

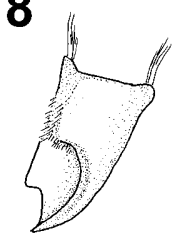

19

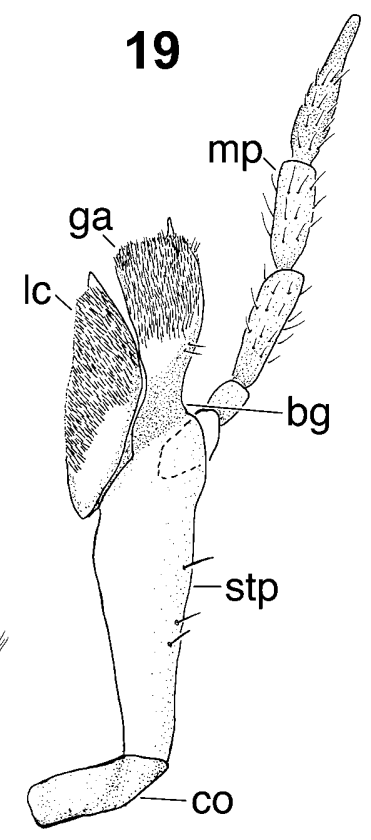

20

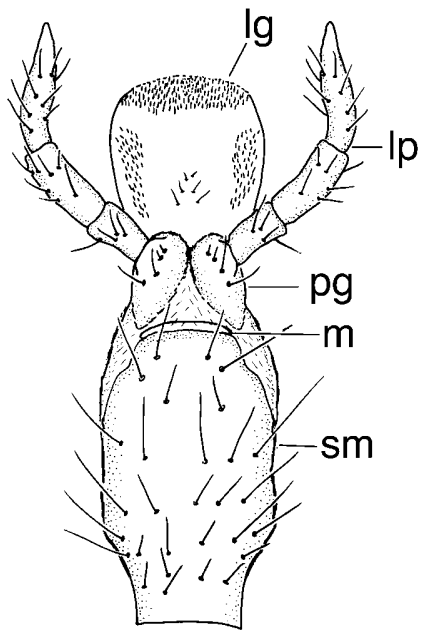

Figs 16-20. Berchmansus elegans, adult head. 16 - frontal view; 17 - antennal segments (left: mesal segment; right: basal two segments); 18 - mandibles, dorsal view; 19 - left maxilla, ventral view; 20 - labium, ventral view. bg - basigalea; co - cardo; ga galea; lbr - labrum; lc - lacinia; lg - ligula; lp - labial palpus; $\mathrm{m}$ - mentum; $\mathrm{mp}$ - maxillary palpus; pfs - postfrontal suture; pg palpiger; sm - submentum; stp - stipe; to - torulus; tp - anterior tentorial pit.

posterior ones smooth, blunt. Segment 10 (Fig. 15). Dorsum with very small setae at apex. Venter with row of four short setae mesally, three pairs of short setae laterally, very small setae apically. Coloration. Dorsum of A1-A7 with white to cream-colored mesal stripe; each segment with pair of transverse brown marks that together form a pair of submesal longitudinal bands; A8 brown; A9, A10 mostly white, each with pair of distinct brown dorsal marks. Venter with A1-A7 white to creamcolored, with mesal brown stripe; A8 dark brown throughout; A9, A10 white, very small brown spots mesally.

\section{Adult (Figs 16-29)}

Body. Medium-sized, robust.

Head (Figs 16-20). Medium-sized, 1.5-1.7 mm wide. Temporal, frontal and postfrontal sutures weak, indistinct; toruli large, distinct, with dorsal margin touching postfrontal suture mesally, diverging slightly dorso-laterally. Labrum emarginate. Eyes relatively small (ratio headwidth : eye-width $=1.7-2.1: 1$ ). Genae short. Antennae (Fig. 17) shorter than wings, 1.06-1.08 cm long; proximal segments of flagellum short (segments 2-4: length = 1.1-1.5 times width), with three concentric rings of setae; middle and distal segments longer (segments 6-9: length = 1.9-2.4 times width), with four concentric rings of setae. Mandibles (Fig. 18) untoothed, asymmetrical, left one with rounded notch on inner margin. Maxilla (Fig. 19) stout, especially distally; cardo distinctly twosegmented; galea stout, broad, with outer and inner margins straight; papilla small; lacinia shorter than inner margin of galea, relatively broad, margins convex; palpi relatively short, stout. Labium (Fig. 20) long, narrow, but not extending beyond maxilla; postmentum (Snodgrass, 1935) (= submentum of Tjeder, 1966) longer than prementum and ligula combined; prementum slightly narrower than postmentum, with distinct palpigers; ligula broad, with convex (arcuate) margin; palpi rather slender. Coloration. Frons dark brown, with white crescentshaped area from eyes to anterior tentorial pits; clypeus dark brown mesally and laterally, cream-colored submesally; labrum brown; genae dark brown; toruli white ventrally, dark brown dorsally. Vertex yellow-green with pair of dark brown stripes laterally. Scape, pedicel and basal segment of flagellum dark brown; remainder of flagellum white becoming tan distally. Labial and maxillary palpi, stipes dark brown; postmentum, prementum, and ligula cream-colored.

Thorax. Prothorax short: $0.65-0.71 \mathrm{~mm}$ long; 1.06-1.19 mm wide. Legs setose. Coloration. Cervix yellow-green, small brown marks laterally. Prothorax yellow-green. Mesothorax, mesocoxa, metathorax, metacoxa dark brown. Otherwise, legs whitish.

Wings. Forewing (Fig. 21) 13.6-15.2 mm long, 5.2-6.3 mm wide; jugal lobe lacking. Costal area broad, with height of tallest costal cells usually three times width; single crossvein in basal part of subcostal area located about midway between first medio-cubital crossvein and furcation of M. First radial crossvein basal to origin of Rs; radial area (between radius and radial sector) with single row of 10-11 cells. 5-6 apparent pseudomedial crossveins; first cubital crossvein (R-M) located at or near second medio-cubital crossvein; cell c1 approximately $0.7 \times$ length of $\mathrm{c} 2$. Two series of gradates; 5-6 inner gradates, 6-7 outer gradates. Vein 1A forked. 

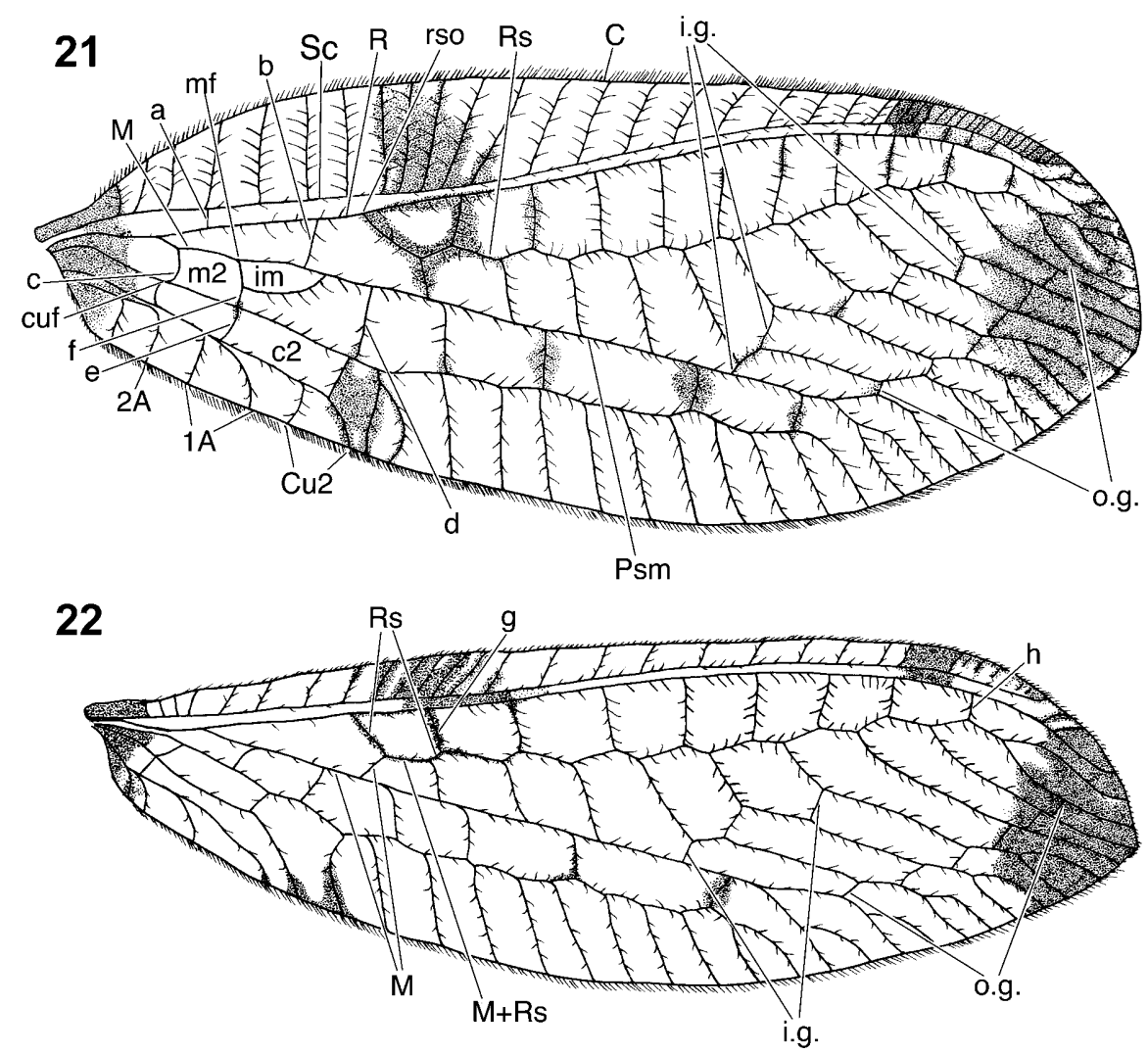

Figs 21-22. Berchmansus elegans, wings. 21 - forewing; 22 - hindwing. $\mathrm{C}-$ costa; c2 - second cubital cell; Cu2 - cubitus; cuf furcation of the cubitus; i.g. - inner gradate series; im - intramedian cell; $\mathrm{M}$ - media; $\mathrm{m} 2$ - second medial cell; mf - furcation of the media; o.g. - outer gradate series; Psm - pseudomedius; R - radius; Rs - radial sector; rso - origin of the Rs; Sc - subcosta; 1A, 2A - first and second anal veins; $a$ - basal subcostal crossvein; $b$ - first radial crossvein; $c$ - first medio-cubital crossvein; $d$ - first pseudomedial crossvein; $\mathrm{e}$ - first cubital crossvein; $\mathrm{f}$ - second medio-cubital crossvein; $\mathrm{g}$ - first radial crossvein; $\mathrm{h}$ - last radial crossvein.

Hindwing (Fig. 22) 12.3-14.1 mm long, 3.8-4.7 mm wide; frenulum not well developed. $\mathrm{M}$ and Rs fused for a short distance near base; 8-9 radial crossveins. Two series of gradates; 3-4 inner gradates, 6-7 outer gradates. Coloration. Hyaline, marked with dark brown spots; veins within spots brown; longitudinal veins pale; most crossveins pale with brown at ends; gradate veins brown.

Abdomen (Figs 23, 26). Callus cerci with approximately 29 trichobothria. Male (Fig. 23): Sternites 2-8 with microtholi, numerous microsetae; sternite 9 without microtholi, with microsetae dense in basal patch. Tergite 9+ectoproct broad, tall, with dorsal apodeme curved slightly upward above callus cercus. Female (Fig. 26): Segment 7, tergite 8 with long setae throughout, dense microsetae except distally on T7, distally and ventrally on T8. Sternite 7 elongate, with apical setae and microsetae in distinct transverse rows. Tergite 9+ectoproct tall, extending ventrally over subgenitale, broader ventrally than dorsally, with long setae throughout, especially dense distally, with patch of microsetae distally, extending above and proximal to callus cercus. Coloration light green except base of segment 1, tergites 3 (anterior region), 4, 5 and 6 , all of segment 7 , base of tergite 8 , and base of sternite $8+9$ (male) dark brown. Tip of abdomen, callus cercus yellowish.
Male genitalia (Figs 23-25). Gonarcus (Figs 23, 25) broadly arcuate, with lateral apodemes extending from thin arch at approximately right angles; lateral apodemes mostly straight, bearing small entoprocessus below mediuncus. Hood attached to membrane between anus and gonarcus, consisting of thin, quadrate dome-like cap with arcuate sides and distal margin forming a sclerotized frame, top of dome consisting of stiff, semi-transparent covering; base of dome membranous; ventral base of hood and internal attachment with dense covering of short setae. Mediuncus (Figs 23, 25) broadly attached to top of gonarcus, forming a thin, tapering, downward curved, shallow projection, with round, bilobed terminus; center of each lobe and midsection raised; mesal beak near terminus. Gonosaccus (Fig. 23) large, delicate, attached to distal end of hood, extending ventrally to tip of S8+9. Hypandrium internum (Figs 23-24) V-shaped, attached to gonosaccus distal to hood. Pair of large, heavily sclerotized, coiled parameres attached to gonosaccus distal to hypandrium internum. In cleared specimens, with genitalia not everted, the parameres are coiled within S8+9, beneath the gonosaccus and gonarcal complex.

Female genitalia (Figs 27-29). Gonapophyses laterales (Fig. 27) narrow, long. Subgenitale (Figs 27, 29) broad, terminus sclerotized, bilobed, with ventral process; base with a heavy membranous fold, small mesal lobe. Sper- 

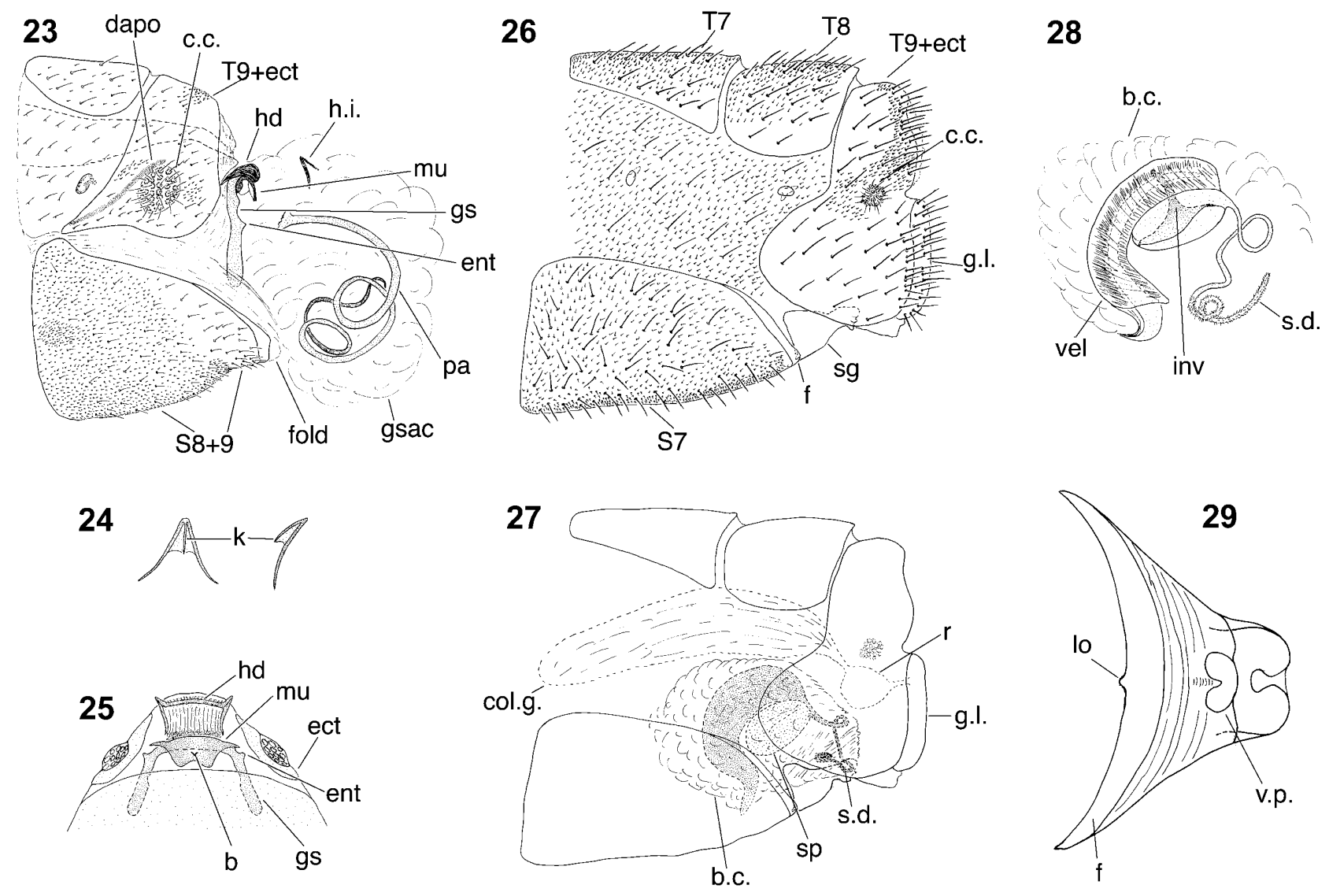

Figs 23-29. Berchmansus elegans, adult. 23-25: Male. 23 - terminal segments of abdomen (lateral); 24 - hypandrium internum (left: dorsal; right: lateral); 25 - gonarcal complex (ventral; gonosaccus, parameres, and hypandrium internum not shown). 26-29: Female. 26 - terminal segments of abdomen (lateral, exterior); 27 - terminal segments of abdomen (interior, lateral); 28 - spermatheca (lateral); 29 - subgenitale (ventral). b - beak of mediuncus; b.c. - bursa copulatrix; c.c. - callus cerci; col.g. - colleterial gland; dapo - dorsal apodeme of T9+ect; ect - ectoproct; ent - entoprocessus; f - fold; g.l. - gonapophysis lateralis; gs - gonarcus (lateral apodeme); gsac - gonosaccus; hd - hood; h.i. - hypandrium internum; inv - spermathecal invagination; $\mathrm{k}$ - keel; lo - lobe; mu - mediuncus; pa - paramere; $\mathrm{r}$ - reservoir; S7 - seventh sternite; S8+9 - fused eighth and ninth sternites; sg - subgenitale; s.d. spermathecal duct; sp - spermatheca; T7 - seventh tergite; T8 - eighth tergite; T9+ect - fused ninth tergite and ectoproct; v.p. - ventral process; vel - velum.

matheca (Figs 27, 28) doughnut-shaped ventrally, with elongate, curved, thick tube-like projection (velum) dorsally; ventral invagination deep, extending from center of round section into velum; spermathecal duct extending from both rounded and elongate sections of spermatheca, elongate, curved and bent, with brushy tip; midsection of duct abutting against terminal section of subgenitale. Bursa copulatrix (Fig. 27) large, completely covering spermatheca, thick-walled distally, delicate, thin anteriorly; no bursal glands observed. Colleterial gland (Fig. 27) delicate, long, extending anteriorly through A7, with distinct reservoir near gonapophyses laterales.

Egg

Ovoid, stalked; $0.751 \mathrm{~mm}$ long, $0.395 \mathrm{~mm}$ wide $(\mathrm{n}=1)$; olive green when newly laid, becoming darker with maturation. Stalk $6.6 \mathrm{~mm}$ long $(\mathrm{n}=1)$, without droplets.

\section{Distribution and seasonal occurrence}

B. elegans is reported from Brazil, Surinam and Costa Rica (Penny, 2002). We collected adults in the Brazilian Atlantic Forest in March, April, May, and November, and the species is reported from Costa Rica in May (Penny, 2002).

\section{Habitat and field observations}

All of the B. elegans adults that we found in the field were resting on the undersides of leaves on trees and shrubs in secondary growth forests. Leaves in these forests tend to have numerous dark blotches that are visible against the sky; the pattern of these blotches provides considerable crypsis for $B$. elegans adults, with their spotted wings.

In general, when seeking B. elegans adults in the field, we found only one or two specimens. However, on one occasion (May 1, 2003), we discovered a large cluster of adults resting on the undersides of leaves of trees in a relatively cool, shady, protected area of approximately 100 square meters within a mixed-species secondary growth forest. We observed these adults in the field through the afternoon until dark; they remained virtually motionless with their wings held flat to the substrate and their abdomens curved to one side or the other. Occasion- 
ally they would sway from side to side or move their wings slightly. We collected 14 males and 10 females (both mature and slightly teneral), but most were left on the trees.

On May 5, we returned to the same area. Again adults were present; we collected eight specimens (four males, four females) and left many others. On this occasion, the adults appeared to be slightly higher in the trees than on the previous trip four days earlier. On both trips, we searched for eggs (on leaves, branches, tree trunks, near the ground, etc.), but none were found. One month later (June 1), our four-person team spent the whole afternoon searching the trees where adults were previously found; the effort resulted in no adults, eggs or larvae in the area. We found only one adult ca. 50 meters away from the site.

\section{Laboratory observations}

Three females oviposited in the laboratory. Eggs were laid singly on long stalks. The maximum number of eggs produced in any one day was four; usually only one or two. The largest number of eggs obtained from a single female was fourteen over a period of five days. Hatching occurred within eight to 12 days of oviposition (temperature variable).

Newly hatched larvae remained on the chorion for several hours; subsequently they walked around the vial with a steady gait or rested on the cotton plug. Larvae were provided water and a mixture of protein hydrolysate of yeast, honey, and sugar, and a variety of prey (e.g, several species of aphids, whiteflies, mealybugs, spider eggs, honeybee larvae and pupae, flies and caterpillars). None were observed to feed on the prey, and all died within four to five days without moulting.

As is typical of many chrysopid taxa, the larvae exhibited trash-carrying behavior. That is, they grasped small pieces of debris with their jaws, curved the upper parts of their bodies dorsally, and placed the debris on the dorsum of their thorax and abdomen. The debris generally remained affixed to the larva's dorsal surface.

\section{DISCUSSION}

\section{Comparative larval morphology}

Few data on belonopterygine and leucochrysine larvae are available for morphological comparison with $B$. elegans. Among the 15 genera of Belonopterygini, larvae are known for two (Italochrysa Principi, 1946, and Calochrysa Banks, 1943) (Principi, 1946; New, 1983, 1986; Díaz-Aranda \& Monserrat, 1995). And, among the seven genera of Leucochrysini, larvae are known for two subgenera of only one genus, Leucochrysa McLachlan, 1868 (subgenera Leucochrysa and Nodita Navás, 1916) (Tauber, 2004; Mantoanelli et al., 2006). Thus, the basis for comparison with B. elegans is small. Nevertheless, given the increased understanding of larval variation among chrysopids that has developed over the past $25+$ years, sufficient data exist for developing testable hypotheses about the generic and higher-level phylogenetic relationships of $B$. elegans.
To initiate the discussion, we propose a series of traits that we consider to have phylogenetic significance and that differentiate the known first instars in the two tribes (Belonopterygini and Leucochrysini). The character states for each of the tribes are derived from descriptions and/or figures contained in the publications listed. To assess the tribal affiliation of Berchmansus, we indicate the character state of the B. elegans first instar within each category.

1. Length of mouthparts. Belonopterygini: shorter than cephalic capsule (New, 1983, 1986; Díaz-Aranda \& Monserrat, 1995). Leucochrysini: longer than cephalic capsule (Tauber, 2004; Mantoanelli et al., 2006). B. elegans: belonopterygine condition (Fig. 1).

2. Mandibles. Belonopterygini: basally stout (basal width approximately one-third length) (New, 1983, 1986). Leucochrysini: narrow (basal width less than onefifth length) (Tauber, 2004: Mantoanelli et al., 2006). $B$. elegans: belonopterygine condition (Fig. 2).

3. Labial palpus, second segment. Belonopterygini: short, stout, much broader than apical segment (New, 1983, 1986). Leucochrysini: elongate, narrow, about same width as apical segment (Tauber, 2004; Mantoanelli et al., 2006). B. elegans: belonopterygine condition (Fig. 4).

4. Flagellum. Belonopterygini: with robust, spur-like subapical seta (New, 1983, 1986). Leucochrysini: with subapical seta unmodified (Tauber, 2004: Mantoanelli et al., 2006). B. elegans: seta greatly enlarged; belonopterygine condition (Fig. 5).

5. Pedicel. Belonopterygini: elongate, tapered (New, 1983, 1986; Díaz-Aranda \& Monserrat, 1995). Leucochrysini: elongate, not noticeably tapered (Tauber, 2004: Mantoanelli et al., 2006). B. elegans: reduced to size of scape; unique (Fig. 5).

6. Cephalic setae (type). Belonopterygini: blunt, ornamented (New, 1983, 1986). Leucochrysini: pointed, smooth (Tauber, 2004; Mantoanelli et al., 2006). B. elegans: belonopterygine condition (Fig. 1).

7. Cephalic setae (position). Belonopterygini: long setae absent from posterior half of head (New, 1983, 1986). Leucochrysini: long setae (e.g., S1) present on posterior half of head (Tauber, 2004; Mantoanelli et al., 2006). B. elegans: belonopterygine condition (Fig. 1).

8. Dorsal thoracic sclerites (Sc1). Belonopterygini: apparently absent or very small (New, 1983, 1986). Leucochrysini: present (Tauber, 2004; Mantoanelli et al., 2006). B. elegans: belonopterygine condition (Figs 6, 7).

9. Thoracic lateral tubercles (LTs). Belonopterygini: lobe-like, broad distally, apically each bearing six or more long lateral setae (LS) (New, 1983, 1986; DíazAranda \& Monserrat, 1995). Leucochrysini: elongate, narrow, each bearing two (prothorax) or three (meso- and metathorax) apical LS (Tauber, 2004; Mantoanelli et al., 2006). B. elegans: leucochrysine condition (Figs 6, 7).

10. Thoracic laterodorsal tubercles (LDTs). Belonopterygini, Leucochrysini: absent from meso- and metathorax (New, 1983, 1986; Díaz-Aranda \& Monserrat, 1995; Tauber, 2004; Mantoanelli et al., 2006). B. elegans: 
present on mesothorax and metathorax, bearing about nine long or medium-length LDS; unique (Fig. 7).

11. Setae associated with lateral tubercles (LS) (thorax and abdomen). Belonopterygini: serrated or rough, blunt (New, 1983, 1986; Díaz-Aranda \& Monserrat, 1995). Leucochrysini: serrated or smooth, pointed (Tauber, 2004; Mantoanelli et al., 2006). B. elegans: rough, hooked (single-pronged and multi-pronged); unique (Fig. 7, 10).

12. Prothoracic dorsal setae. Belonopterygini and Leucochrysini: anterior margin of pronotum without a row of setae. B. elegans: pronotum margined anteriorly by a row of long, hooked setae on rounded chalazae; unique (Fig. $6)$.

13. Thoracic dorsal setae. Belonopterygini: meso- and metathoraces with transverse rows of numerous hooked submedian setae (SMS) (New, 1983, 1986; Díaz-Aranda \& Monserrat, 1995). Leucochrysini: meso- and metathoraces each with at most a single row of four hooked or pointed setae (Tauber, 2004; Mantoanelli et al., 2006). B. elegans: belonopterygine condition (Fig. 7).

14. Abdominal laterodorsal tubercles (LDTs). Belonopterygini: not mentioned by either New $(1983,1986)$ or Díaz-Aranda \& Monserrat (1995). Leucochrysini: present on A1-A5, each with two long, smooth, hooked LDS (Tauber, 2004; Mantoanelli et al., 2006). B. elegans: present on A1-A5, each with four to six long or mediumlength, hooked LDS (Figs 9, 10).

15. Abdominal dorsal setae (SMS). Belonopterygini: A1-A6 each with transverse rows of numerous hooked setae (New, 1983, 1986; Díaz-Aranda \& Monserrat, 1995). Leucochrysini: A1: with single row of four long, hooked SMS; A2-A5, each with two rows of four and two long, smooth, hooked SMS (Tauber, 2004; Mantoanelli et al., 2006). B. elegans: belonopterygine condition (Figs 9, 10, 11).

\section{Comparative adult morphology}

Among the chrysopid tribes, adults in the Leucochrysini have received the least attention from modern systematists (the primary synthesis of adult characters being that of Brooks \& Barnard, 1990). Synapomorphies for the genera and the tribe are not well defined, and the monophyly of the tribe is in question.

In contrast, some regional belonopterygine faunae (adults) have received modern systematic treatment (primarily by Tjeder, 1966; also Tsukaguchi, 1995). Consequently, the adult characteristics of genera in the tribe are reasonably well defined, a number of synapomorphies that have been proposed for belonopterygine adults, and the tribe is considered to be monophyletic (Brooks \& Barnard, 1990).

Unfortunately, in many cases, the characteristics that Brooks \& Barnard (1990) described for the Belonopterygini overlap with those proposed for leucochrysine adults. Therefore, for our comparison with B. elegans we chose those that appear to differentiate the two tribes. Below, we discuss each.

1. Maxillary and labial palps. Leucochrysini: tapered apically; Belonopterygini: round apically.
B. elegans fits the description for Belonopterygini (Figs 19, 20). However, it is noteworthy that our observations of the palps on numerous leucochrysines show considerable variation among taxa, and that Tjeder (1966) and Tsukaguchi (1995) provide numerous examples of variation among belonopterygine genera and species. Thus, the value of this character in diagnosing the tribes is questionable.

2. Mandibles. Leucochrysini: asymmetrical, left mandible with distinct, pointed tooth; Belonopterygini: broad, more or less symmetrical, untoothed, with small basal tooth on both mandibles, or with broad basal tooth on left mandible.

Although the B. elegans mandibles (Fig. 18) are asymmetrical (the left one has a round notch on the inner margin), they are not toothed. Thus, B. elegans resembles the belonopterygine condition more than the leucochrysine.

3. Toruli. Leucochrysini: small; Belonopterygini: usually large.

In B. elegans the toruli are relatively large (Fig. 16), at least as large as those illustrated for Dysochrysa Tjeder, 1966. Moreover, they contact the postfrontal suture as Tjeder (1966, Fig. 1133) showed for some belonopterygines.

4. Antennal length. Leucochrysini: 1.5 or more times longer than forewing; Belonopterygini: variable.

In $B$. elegans the antenna is $\sim 0.75$ the length of the forewing; thus it does not fall within the leucochrysine condition.

5. Flagellar segments. Leucochrysini: three or more times as long as broad; Belonopterygini: at most two times as long as broad.

In B. elegans, the length : width ratio of the flagellar segments ranges from 1.1 to 2.2 (Fig. 17); thus, it more closely resembles the belonopterygine condition.

6. Flagellar setae. In both Leucochrysini and Belonopterygini, the flagellar setae typically are arranged in four rings per segment (Tjeder, 1966; Brooks \& Barnard, 1990).

In B. elegans, most antennal segments fit this description, but some of the proximal flagellar segments have only three rows of setae (Fig. 17). In this regard, B. elegans is similar to the belonopterygine genus Dysochrysa (see Tjeder, 1966, p. 335).

7. Forewing. Leucochrysini: cell $\mathrm{c} 1$ shorter than $\mathrm{c} 2$; Belonopterygini: cell $\mathrm{c} 1$ longer than $\mathrm{c} 2$.

In B. elegans, c1 is $\sim 0.7 \times$ the size of $\mathrm{c} 2$ (Fig. 21 ); thus it more closely resembles the typical leucochrysine condition. Nevertheless, it is noteworthy that in at least two belonopterygine species in two genera [Nesochrysa seyrigi (Navás, 1934) and Belonopteryx arteriosa Gerstaecker, 1863] c1 is shorter than c2 (see Brooks \& Barnard, 1990). Thus, the value of the character in differentiating the tribes is open to reassessment.

8. Male genitalia - parameres. Leucochrysini: parameres absent; Belonopterygini: parameres usually present.

In B. elegans, a pair of long, coiled, sclerotized structures arises from the gonosaccus (Fig. 23); within the 
abdomen and on inflated specimens, these structures lie beneath the gonarcus in the position where parameres occur. These coiled structures are similar to the parameres in some other neuropteran families (e.g., Berothidae and Rhachiberothidae; e.g., Tjeder, 1959; Aspöck \& Aspöck, 1980, 1986; Aspöck \& Mansell, 1994), but they are very unusual among chrysopids (see Brooks \& Barnard, 1990). Given their position and the otherwise broad range of variability among chrysopid parameres (e.g. see Tjeder, 1966; Brooks \& Barnard, 1990), we interpret these structures to be an elaborate form of parameres. [It is noteworthy that Brooks \& Barnard (1990) did not report or illustrate structures like these in their treatment of $B$. elegans (see discussion below).]

9. Female - praegenitale. Leucochrysini: praegenitale [sclerotized structure separate from and anterior (ventral) to the subgenitale lobes] absent; Belonopterygini: praegenitale usually present.

In B. elegans, there is no distinct praegenitale (Figs 27, 28). However, the anterior margin of the subgenitale has a lobate structure that in a few Leucochrysini [e.g., Leucochrysa (L.) insularis (Walker, 1853)] and some Belonopterygini [e.g., species of Oviedus Navás, 1913 (= Nesochrysa Navás, 1910)] has been presumed to be the precursor of the praegenitale (Tjeder, 1966, p. 324). Thus, in respect to this trait, $B$. elegans falls within the range of both tribes.

10. Female - Spermatheca. The spermathecae of Belonopterygini and Leucochrysini exhibit a variety of shapes and sizes. The B. elegans spermatheca, with its doughnut-shaped ventral portion, elongate, curved, tubelike dorsal section, deep ventral invagination, and slender coiled duct (Fig. 29), closely resembles the spermathecae of the belonopterygine genus Oviedus (= Nesochrysa) (described and figured by Tjeder, 1966, pp. 325-335). Indeed, Tjeder noted the similarity between the Oviedus spermatheca and that of many Leucochrysa. Thus, the $B$. elegans spermatheca falls within the range of both tribes.

\section{Tribal affiliation and prey association}

On the basis of the numerous shared character states described above, it is clear that B. elegans belongs in the tribe Belonopterygini. At this point, B. elegans does not appear to fall into any previously described belonopterygine genus, and the monophyly of Berchmansus is in question. We do not have larval specimens of the other two species of Berchmansus, and we have not yet examined the very few known adult specimens of these species. Thus, we cannot confirm their tribal affiliations or their relationships with $B$. elegans, and until we can do so, we will refrain from naming a new genus for $B$. elegans.

Our study increases the number of known belonopterygine genera to 15 , four of which occur in the New World: Abachrysa Banks, 1938 (southeastern USA), Belonopteryx Gerstaecker, 1863 (Argentina, southern Brasil), Nacarina Navás, 1915 (Neotropics, southeastern USA), and now, the genus that contains B. elegans (Neotropics).
Belonopterygine larvae are generally associated with ant nests (Italochrysa: Principi, 1943, 1946; Nacarina: Weber, 1942; Abachrysa, E.G. MacLeod, unpubl.). In Italochrysa italica (Rossi, 1790) (= Nothochrysa italica Rossi, 1790), eggs are laid on tree trunks and wooden posts near ant (Crematogaster scutellaris Olivier, 1791) nests. The trash-carrying larvae are very mobile; Principi (1943, 1946) observed them grasping and feeding on brood being carried by worker ants. Nacarina valida (Erichson, 1848) (= Nadiva valida Erichson, 1848) larvae were reported to be an unusual blue color, very active, and closely associated with Camponotus abdominalis (Fabr., 1804) adults and larvae (Weber, 1942). It now seems likely that our failure to rear B. elegans resulted from a lack of suitable prey (ants).

\section{Species- or genus-specific traits}

In comparing $B$. elegans with species in other belonopterygine genera, certain traits stand out as unique or unusual. Specifically, the adult has a remarkable quadrate hood above the gonarcus and highly modified parameres on the gonosaccus. In addition, the first instar has a greatly enlarged subapical seta on the flagellum, a row of submedian setae on the anterior margin of the pronotum, setose laterodorsal tubercles on the meso- and metathorax, and multi-pronged setae on the thoracic and abdominal tubercles. Most of these characteristics are reported for no other chrysopids. One of our goals is to assess whether these traits are diagnostic at the species or higher levels; an answer to this question would be of considerable value in understanding the diversity and phylogeny of New World chrysopids.

\section{Variation in published descriptions of $\boldsymbol{B}$. elegans}

It is also noteworthy that several features of the male genitalia that Brooks \& Barnard (1990) described for $B$. elegans differ markedly from those in our specimens. For example, Brooks and Barnard did not mention or illustrate the coiled structures (parameres), described above. Also, the quadrate dorsal hood that we observed in our specimens is absent from their illustration, but they report an arcuate structure ventral to the gonarcus on their specimens that is not present on ours. Two explanations can account for these differences: First, the genitalia of chrysopid males typically undergo substantial changes during maturation (Adams, 1977, 1987; Tauber, 2003); it is possible that sexual maturation in B. elegans includes striking alterations in male genital structures. In this case, Brooks \& Barnard's (1990) specimens and ours may encompass a single, very distinctive, but developmentally variable species (B. elegans). We have not identified teneral males among our specimens, so this possibility cannot be tested now.

A second possibility is that Brooks and Barnard's specimens and ours represent different, but cryptic, species in which the distinctive external adult features are similar, but the genitalia differ markedly. To stabilize $B$. elegans' taxonomic status, and thus resolve the identity of Brooks and Barnard's and our specimens, will require us to examine their specimens, as well as the type specimens 
of B. elegans (see footnote p. 2). Meanwhile, to preclude possible confusion over the identity of our specimens, we are depositing vouchers in several museums (see Material and Methods).

ACKNOWLEDGMENTS. We thank E.A. Silva, P.J. Tauber, and A.J. Tauber for help in obtaining adult specimens. Our work was supported by the National Science Foundation (Grants INT 9817231 and INT 9912449), the National Geographic Society, Conselho Nacional de Desenvolvimento Científico e Tecnológico (CNPq, Brazil - Grants 300504/96-9 and 466439/00-8), the National Research Initiative - USDA Cooperative State Research Education and Extension Service (Grants 9802447 and 2002-35316-12231), Regional Project W-1185, Cornell University, and Universidade Estadual do Norte Fluminense. We (CAT, MJT) also thank J.A. Powell, Department of Entomology, University of California, Berkeley, as well as L.E. Ehler, R.E. Page, L.S. Kimsey, S. Soucy-Lubell, D.E. Ullman, and the Department of Entomology, University of California, Davis for their help and cooperation in a variety of ways. The manuscript benefited from the careful reviews of U. Aspöck and S.J. Brooks.

\section{REFERENCES}

ADAms P.A. 1977: Taxonomy of United States Leucochrysa (Neuroptera: Chrysopidae). Psyche 84: 92-102.

ADAms P.A. 1978: Zoogeography of New World Chrysopidae, a progress report. Folia Entomol. Mexicana 39-40: 210-211.

Adams P.A. 1979: A new species of Leucochrysa from Mexico (Neuroptera, Chrysopidae). Folia Entomol. Mexicana 41: 95-101.

ADAms P.A. 1987: Studies in neotropical Chrysopidae (Neuroptera) III. Notes on Nodita amazonica Navas and N. oenops, $n$. sp. Neuroptera Int. 4: 287-294.

Aspöck U. \& Aspöck H. 1980: Das Genus Isoscelipteron Costa, 1863 (Neuropteroidea: Planipennia: Berothidae). Z. Anbeitsgem. Öst. Entomol. 32: 65-74.

Aspöck U. \& AsPöck H. 1986: Die Berothiden Australiens III: Die Genera Spermophorella Tillyard and Quasispermophorella n. g. (Neuropteroidea: Planipennia: Berothidae). $Z$. Anbeitsgem. Öst. Entomol. 38: 17-34.

AsPöck U. \& Mansell M.W. 1994: A revision of the family Rhachiberothidae Tjeder, 1959, stat. n. (Neuroptera). Syst. Entomol. 19: 181-206.

Aspöck U., Plant J.D. \& Nemeschkal H.L. 2001: Cladistic analysis of Neuroptera and their systematic position within the Neuropterida (Insecta: Holometabola: Neuropterida: Neuroptera). Syst. Entomol. 26: 73-86.

BRoOKS S.J. \& BARNARD P.C. 1990: The green lacewings of the world: a generic review (Neuroptera: Chrysopidae). Bull. Br. Mus. Nat. Hist. (Entomol.) 59: 117-286.

Díaz-Aranda L.M. \& Monserrat V.J. 1995: Aphidophagous predator diagnosis key to genera of European chrysopid larvae (Neur.: Chrysopidae). Entomophaga 40:169-181.

GrebenNikov V.V. 2004: Grub-like larvae of Neuroptera (Insecta): a morphological review of the families Ithonidae and Polystoechotidae and a description of Oliarces clara. Eur. J. Entomol. 101: 409-417.

Mantoanelli E., Albuquerque G.S., Tauber C.A. \& Tauber M.J. 2006: Leucochrysa (Leucochrysa) varia (Schneider) (Neuroptera: Chrysopidae): larval descriptions, developmental rates, and adult color variation. Ann. Entomol. Soc. Am. 99 (in press).
Monserrat V.J., Oswald J.D., Tauber C.A. \& Díaz-Aranda L.M. 2001: Recognition of larval Neuroptera. In McEwen P., New T.R. \& Whittington A.E. (eds): Lacewings in the Crop Environment. Cambridge University Press, Cambridge, pp. 43-81.

NAvÁs L. 1913: Les chrysopides (Ins., Névr.) du Musée de Londres. Ann. Soc. Sci. Bruxelles 37: 292-330.

New T.R. 1983: The egg and first instar larva of Italochrysa insignis (Neuroptera, Chrysopidae). Aust. Entomol. Mag. 10: 29-32.

New T.R. 1986: Some early stages of Calochrysa Banks (Neuroptera, Chrysopidae). Aust. Entomol. Mag. 13: 11-14.

Penny N.D. 2002: A guide to the lacewings (Neuroptera) of Costa Rica. Proc. Calif. Acad. Sci. 53: 161-457.

PrinciPI M.M. 1943: La Nothochrysa italica Rossi. Ed I Suoi singolari costumi (Neuroptera - Chrysopidae). Boll. Soc. Entomol. Ital. 75: 117-118.

PrincIPI M.M. 1946: Contributi allo studio dei "Neurotteri" Italiani. IV. Nothochrysa italica Rossi. Boll. Inst. Entomol. Univ. Bologna 15: 85-102.

Rousset A. 1966: Morphologie céphalique des larves des Planipennes (Insectes, Névroptéroïdes). Mém. Mus. Nat. Hist. (Ser. A) 42: 1-199.

SNODGRASS R.E. 1935: Principles of Insect Morphology. McGraw-Hill, New York, 667 pp.

Stange L.A. \& Miller R.B. 1990: Classification of the Myrmeleontidae based on larvae (Insecta: Neuroptera). In Mansell M.W. \& Aspöck H. (eds): Advances in Neuropterology. Proc. III International Symposium on Neuropterology, Berg en Dal, Kruger National Park, Republic of South Africa. Dept. Agric. Development, Directorate of Agric. Information, Pretoria, pp. 151-169.

TAUBER C.A. 2003: Generic characteristics of Chrysopodes (Neuroptera: Chrysopidae), with new larval descriptions and a review of species from the United States and Canada. Ann. Entomol. Soc. Am. 96: 472-490.

TAUBer C.A. 2004: A systematic review of the genus Leucochrysa (Neuroptera: Chrysopidae) in the United States. Ann. Entomol. Soc. Am. 97: 1129-1158.

TAuber C.A. \& De LÉON T. 2001: Systematics of green lacewings (Neuroptera: Chrysopidae): Larvae of Ceraeochrysa from Mexico. Ann. Entomol. Soc. Am. 94: 197-209.

Tauber C.A., De Léon T., Lopez Arroyo J.I. \& Tauber M.J. 1998: Ceraeochrysa placita (Neuroptera: Chrysopidae): generic characteristics of larvae, larval descriptions, and life cycle. Ann. Entomol. Soc. Am. 91: 608-618.

Tauber C.A., De Léon T., Penny N.D. \& Tauber M.J. 2000; The genus Ceraeochrysa (Neuroptera: Chrysopidae) of America north of Mexico: larvae, adults and comparative biology. Ann. Entomol. Soc. Am. 93: 1195-1221.

TJEDER B. 1959: Neuroptera - Planipennia. The Lace-wings of Southern Africa. 2. Family Berothidae. Sth Afr. Anim. Life 6: 256-314.

TJEDER B. 1966: Neuroptera - Planipennia. The Lace-wings of Southern Africa. 5. Family Chrysopidae. Sth Afr. Anim. Life 12: $228-534$.

Tsukaguchi S. 1995: Chrysopidae of Japan (Insecta, Neuroptera). By the author, Hyogo, Japan, 223 pp.

Weber N. 1942: A neuropterous myrmecophile, Nadiva valida Erichs. Psyche 49: 1-3.

Received March 23, 2005; revised and accepted October 5, 2005 